Demand for Environmental Goods: Evidence from Voting Patterns on California Initiatives

\author{
by \\ Matthew Kahn, Columbia University \\ John G. Matsusaka, Stanford University
}

August 1995

1994-95 Discussion Paper Series No. 737

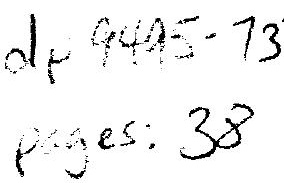




\title{
DEMAND FOR ENVIRONMENTAL GOODS: EVIDENCE FROM VOTING PATTERNS ON CALIFORNIA INITIATIVES*
}

\author{
MATTHEW E. KAHN
}

Department of Economics, Columbia University, New York, NY 10027

\section{JOHN G. MATSUSAKA}

Hoover Institution, Stanford University, Stanford, CA 94305-6010,

Department of Finance and Business Economics, School of Business Administration, University of Southern California, Los Angeles, CA 90089-1421

\begin{abstract}
This paper studies voting behavior on 16 environmental ballot propositions in California in order to characterize the demand for environmental goods. The environment is found to be a normal good for people with mean incomes, but some environmental goods are inferior for people with high incomes, at least when supplied collectively. An important "price" of environmental goods is reduced income in the construction, farming, forestry, and manufacturing industries. In most cases, income and price can explain most of the variation in voting; it is not essential to introduce non-economic concepts such as ideology and politics.
\end{abstract}

* We received helpful comments from Chris Acito, Edward Glaeser, Douglas Joines, John Lott, Peter Pashigian, Andrew Rutten, Mark Zupan, and seminar participants at The University of Chicago and the University of Southern California. Financial support was kindly provided by the Olin Foundation (through a grant to the Center for the Study of the Economy and the State at The University of Chicago), The University of Chicago, and the School of Business Administration at USC. 


\section{Introduction}

The environment is a good and as such should be amenable to conventional economic demand analysis. However, because it is a public good, attempts to estimate its demand function confront obstacles that are absent when studying private goods, notably, the fact that individual price-quantity transactions are not observed. This has made it difficult to resolve even the most basic questions about environmental demand. Is the environment a normal or inferior good? What are the prices of environmental goods, and who pays them? Can environmental demand be understood in terms of prices and income, or is it necessary to consider non-economic factors such as ideology and politics?

Researchers have attempted to answer these questions using a variety of methodologies, none of them immune to criticism. ${ }^{1}$ Perhaps the most popular technique is contingent valuation, which estimates willingness-to-pay by conducting interviews where the subject is asked to make choices under a hypothetical budget constraint; however, the demand functions yielded by such surveys often are inconsistent with economic theory, leading some researchers to conclude that contingent valuation surveys do not measure the preferences they attempt to measure [Hausman, 1993; Diamond and Hausman, 1994]. Hedonic wage and rental studies measure the capitalized value of environmental goods to the marginal person, but provide only limited information on inframarginal values, and are poorly suited to estimate the value of environmental goods that are not localized, such as preservation of endangered species. Studies that try to infer demand from the relation between roll call votes of legislators and characteristics of constituents have been challenged on the grounds that representatives vote according to their personal ideologies rather than constituent interests [Kalt and Zupan, 1984]. Similarly, studies that measure demand by linking environmental quality directly to national income and other aggregate variables also rely on the assumption that government policies faithfully reflect the desires of the electorate.

An alternative way to estimate environmental demand is with voting data from environmental ballot propositions. Propositions present voters with a simple yes-or-no choice whether to increase the provision of some environmental good. Under the assumption that those with the highest value for the good are the most likely to vote in favor, the demand function can be inferred by identifying the prices faced by each person and observing how he votes. Individual voting decisions effectively take on the role that individual consumption decisions play in conventional demand analysis. The ballot proposition method of estimating environmental demand does not suffer from the problems that arise with other methods;

1 For examples, see Mitchell and Carson [1989] on contingent valuation, Blomquist, Berger, and Hoehn [1988] on hedonic pricing, Pashigian [1985] on voting patterns of elected representatives, and Coursey [1992] on the linking of macro data to outcomes. 
the issues to be decided are real, the decisions are binding, a lengthy pre-election campaign period exposes voters to arguments for and against and allows time for reflection, ${ }^{2}$ a wide variety of issues are considered, and there are no intervening political agents. Deacon and Shapiro [1975] developed the theoretical underpinnings for this approach and applied it to two specific issues with suggestive but promising results. Aside from Fischel [1979], however, the potential of the ballot proposition approach remains largely unexploited.

Our purpose in this paper is to characterize demand for the environment by studying voting behavior on 16 different environmental ballot propositions in the state of California. During the last three decades, California voters registered their opinions on a rich menu of proposed environmental laws. The subjects of the measures ranged from protecting mountain lions and expanding parklands to imposing a bottle deposit and tightening restrictions on pesticides and toxic wastes. Our data set includes the universe of environmental initiatives that came before the state's electorate between 1970 and 1994. It was created for this study by merging county vote totals on each initiative with demographic and economic variables. One advantage of considering a wide assortment of issues is that it allows an assessment to be made of the robustness of the findings. If similar voting patterns are observed across a number of issues, we can be more confident that the results are not driven by subtle unmeasured proposition-specific factors.

For each proposition, we estimate a cross-sectional voting regression in which the independent variables include income and proxies for the price. The estimates, taken as a group, provide answers to three fundamental questions about demand for the environment. First, is the environment a normal or inferior good? Deacon and Shapiro [1975] and Fischel [1979] found mixed evidence of a positive income effect, but the former study expressed concern that its income variable might be capturing price effects. Contingent valuation studies typically report income elasticities between 0 and 1 , but these elasticities are too low to be consistent with concurrent findings of large divergences between willingness-to-pay and willingness-to-accept ${ }^{3}$ (see Diamond and Hausman [1994] and the references therein.) Only two legislative studies of which we are aware included an income variable, and both found insignificantly positive coefficients [Pashigian, 1985; Fort, Hallagan, Morong, and Stegner, 1993]. And the three studies using aggregate data each reported a significant positive income relation, but only Coursey [1992] tried to control for prices and the control was crude. Taken

\footnotetext{
2 Unlike opinion polls, which may change substantially as an election draws near, the final poll on election day is remarkably stable-it is difficult to think of a single initiative decision that was reversed in a short period of time.

3 Roughly speaking, willingness-to-pay and willingness-to-accept differ by the income effect; thus, large differences imply large income effects.
} 
together, the evidence points weakly but not convincingly toward the environment being a normal good. Our estimates support this conclusion, but with some qualifications. We find a robust concave relation between income and pro-environment voting across a wide range of issues, and the point estimates indicate that the environment is a normal good at mean income levels. However, at the highest income levels, we find statistically significant evidence that certain environmental goods are inferior, particularly park lands. We suggest this does not mean that parks per se are inferior at high income levels, but that public provision of such goods is; the wealthy may have access to privately-provided park areas, leading them to oppose additional public provision.

Demand analysis is useful only to the extent that the relevant prices can be identified. A second question is, what is the "price" of environmental goods, and who pays it? We explore the hypothesis that an important price (or, more naturally, "cost") of providing environmental goods is a loss of income to people employed in particular industries and occupations. Consistent with this view, the regressions indicate that industry and proxies for occupation are good predictors of voting on environmental initiatives. That economic interests affect voting is neither new nor surprising. What is novel is the finding that the configuration and identity of interest groups appears to be stable across widely varying issues and over time: people in construction, farming, forestry, and manufacturing, and lesseducated people in general are opposed; highly-educated urban dwellers are in favor. This result provides a thumbnail sketch of the political economy of environmental regulation, and as we discuss below presents a theoretical puzzle of sorts.

measures sponsored by industry groups to ease environmental regulations. The measures, on their face, looked like other

Our approach assumes that the environment can be understood much like any other good, in terms of price and income effects. However, it is often argued that economics is an unproductive way to study the environment because non-economic factors like ideology and politics predominate. ${ }^{4}$ A third question we investigate is whether it is fruitful to study the environment purely from an economics perspective. Put differently, how important is it to consider politics and ideology when studying voting on environmental initiatives? We do not attempt to determine what "really" motivates people, rather we follow the lead of Peltzman [1984] and consider the narrower methodological question, is it necessary to incorporate ideology and politics to explain voting patterns, or can researchers simply proceed as if income and prices were sufficient? If it is possible to explain environmental voting entirely with variables linked to price and income, then the relevance of ideology and politics is

4 "By and large, the (economics) profession accepts the notion that social welfare and not private interest is the guiding principle for environmental legislation and regulation," Pashigian [1985: pages 551-552]. 
moot for practical purposes. We find that income and price proxies can explain most of the variation in voting behavior. Moreover, when a variable representing political ideology, party registration, is introduced, it adds relatively little explanatory power. Economists tend to suspect that ideology and political preferences are proxies for deeper economic interests. Our results suggest that it is a reasonable approximation to conduct research on the environment as if this were true.

The plan of the paper is the following. Section 2 provides background information on the initiative in California. Section 3 describes the data and methods. The set of environmental initiatives are presented along with summary statistics. An empirical model is developed and the data sources are reported. Section 4 presents the results in four subsections. This first subsection examines income effects, the second looks at price effects, the third considers industry-sponsored "counter-initiatives" that would have eased environmental regulations, and the fourth addresses politics and ideology. Section 5 summarizes and concludes.

\section{The Initiative in California}

The initiative is a legislative device that allows citizens to propose and approve laws without recourse to their elected representatives. In California, the initiative was made available at the state level in 1911 as part of a set of reforms associated with the Progressive movement. The initiative and other direct democracy devices like the referendum and recall were promoted by the Progressives as a partial solution to their central concern, the apparent capture of representative government by special interests.

The mechanics of the initiative vary by location, but the basic features are the same. In order to qualify an initiative for the ballot, its sponsors must collect the signatures of a given number of registered voters. If petitioners collect enough signatures, the measure appears on the next election ballot, and if it receives a majority of the votes becomes law. An initiative can take the form of a statute or a constitutional amendment. Since 1966, the number of signatures required to qualify a statutory initiative for the California ballot is 5 percent of the number of votes cast in the preceding gubernatorial election; the signature requirement for a constitutional amendment initiative is 8 percent.

Citizens in California and most other states also vote on measures that are not initiatives. One class of propositions are placed on the ballot by the legislature, rather than by citizen petition. These are usually called "referred" or "legislative" measures. Another class of propositions comes to the ballot by petition, but asks the voters to approve or reject an existing piece of legislation that originated in the legislature. These are typically called "referendums," or sometimes "plebiscites." Our study focuses on California initiatives 
over 1970-1994. During this period, the electorate voted on 98 initiatives, 266 legislative measures, and 4 referendums, approving 40 percent, 73 percent, and zero percent of them respectively. Matsusaka [1992] provided an economic framework to understand why certain issues appear as initiatives and others do not, and contains more extensive background information.

\section{Data and Methods}

\section{Environmental Initiatives}

From the universe of California initiatives in the 1970-1994 period we identified 16 that primarily concerned the environment. The year 1970 is sometimes cited as the birth year of the modern environmental movement; it contained both the passage of the federal Environmental Protection Act and the first celebration of Earth Day. Our admittedly subjective definition of an environmental initiative was an initiative that addressed the supply of pollution, natural resources, or wildlife. This is a less expansive definition of the environment than some environmental groups have adopted. As a result, we eliminated from our study a number of measures in which environmental organizations have taken an interest, such as Proposition 97 in 1988 that proposed to restore funding to the California Occupational Safety and Hazard Administration. We also eliminated measures that dealt only tangentially with the environment, like Proposition 11 in the 1980 primary election that proposed to levy a profit surtax on oil companies, 5 percent of which was to be diverted to environmental preservation. It should be noted as well that we do not consider non-initiative environmental ballot measures in this study. The omitted legislative measures, primarily bond authorizations for environmental projects, and the Peripheral Canal referendum in 1982, would be interesting to consider in their own right, but exceed the bounds of this study.

Table 1 chronologically lists the environmental initiatives and provides summary information on each of them. The first column indicates the year each measure appeared on the ballot, its official number, and a brief description of its topic; longer descriptions appear in the appendix.. ${ }^{5}$ The remaining columns in Table 1 indicate the percentage of votes cast in favor statewide, the number of counties (out of 58) in which yes votes exceeded no votes, and the percentage of favorable votes in the least and most favorable county.

All of the initiatives were widely expected to increase the supply of environmental goods except Propositions 135 and 138 on the 1990 ballot. Propositions 135 and 138 were sponsored by business groups in an attempt to defuse a perceived threat from Propositions 128 and 130 ,

5 The information was drawn from California Journal and the Los Angeles Times. 
respectively, on the same ballot. Both "counter-initiatives" were opposed by most environmental organizations and arguably would have reduced the supply of environmental goods. Proposition 9 in 1972 did not attract support or opposition from prominent environmental organizations, who considered it in the right direction but too extreme. The rest of the initiatives in Table 1 were endorsed by at least one prominent environmental organization, such as the Sierra Club, Audobon Society, or National Wildlife Federation.

More often than not environmental initiatives have been unsuccessful; only 6 of the 16 measures were enacted. The highwater period appears to have been 1986-1990. During these years, of the initiatives endorsed by environmental organizations, what we call "proenvironment" propositions for short, 5 of 7 passed, compared to 1 of 7 outside the period. As measured by votes in favor, the most popular initiative, with 65.1 percent approval, was Proposition 70 in 1988, authorizing a $\$ 776$ million bond issue to buy wildlife and park lands. The least popular measure was Proposition 185, an initiative to increase gas taxes and use the proceeds for mass transit systems, parks, natural habitats, and wetlands, which received only 19.5 percent votes in favor. A substantial variation in approval rates across counties is present. $^{6}$

\section{Empirical Model}

We are interested in characterizing the demand for environmental goods. I general formulation of demand for a particular good would be $D(I, P, X)$, where $I$ is the consurner's income, $P$ is the price he must pay for the good, and $X$ represents his preferences. The problem with collectively supplied goods, as noted above, is that individual prices and quantities are not observed, leaving only indirect methods to characterize $D$.

Our approach is to use weighted least squares to estimate the following equation for each initiative:

$$
\ln \left(\frac{F_{i}}{1-F_{i}}\right)=\beta_{0}+\beta_{1} I_{i}+\beta_{2} P_{i}+\beta_{3} X_{i}+u_{i}
$$

In this equation, $i=1, \ldots, 57$ indexes a county, ${ }^{7} F_{i}$ is the fraction of votes cast in favor in county $i$, that is,

$$
F_{i}=\frac{\text { Votes in favor }}{\text { Votes in favor }+ \text { Votes against }}
$$

6 We calculated, but do not report, how frequently each county voted for the "pro-environment" position. The most supportive counties were in the San Francisco Bay area, with San Francisco County being far and away the "greenest" county. The most negative counties toward environmental initiatives were in the extreme north of the state, the northern valleys, and the San Joaquin Valley. The bellweather counties were Sacramento, Solano, and the metropolitan counties surrounding and including Los Angeles.

7 We omit tiny Alpine county near Lake Tahoe because a majority of the registered voters in the county only live there part of the year; the census information for the county is unlikely to represent the characteristics of its voters. 
$u_{i}$ is a disturbance term, and $\beta_{j}$ are unknown parameters to be estimated. Each observation is weighted by $\left(n_{i} F_{i}\left(1-F_{i}\right)\right)^{1 / 2}$ to control for heteroskedasticity, where $n_{i}$ is the number of votes cast in county $i$ [Maddala, 1983].

The idea behind equation ( 1 ) is intuitive. Each voter registers his preference on a proposed increase in the quantity of a particular environmental good (or a decrease in the case of Propositions 135 and 138). By linking his vote to his income and prices, a picture of his underlying demand emerges. In a sense, voting decisions are used in place of the missing consumption decisions. The main advantage of studying voting on initiatives rather than in legislatures is that we observe directly the electorate's preferences instead of having to infer them through the filter of representatives' roll call votes.

The log-of-the-odds formulation is common in studies using voting data on ballot propositions, for example, Schroeder and Sjoquist [1978], Filer and Kenny [1980], and Dubin, Kiewiet, and Noussair [1992]. It is a simplified version of the approach in Deacon and Shapiro [1975]. Dubin, Kiewiet, and Noussair [1992] developed conditions under which the $\beta_{j}$ parameters can be interpreted as parameters in the utility function of a representative consumer, and also provided a theoretical rationale for our choice of weights. ${ }^{8}$

Although microfoundations have been provided for our approach, the validity of the assumptions required to justify them has not been established empirically. A cautious interpretation of the estimates would be as reduced form parameters. The main reason we use aggregate data in this paper is that comparable survey data are not available. A prominent study by Fischel [1979] used data from a survey that he conducted to study voting on environmental measures in New Hampshire localities. He concluded that the technique of analyzing data from individual voters gave results similar to those utilizing community averages, and consequently provided some justification for the employment of aggregate data in such tasks. Nevertheless, it should be kept in mind that our study employs ecological regressions, and the usual caveats apply.

Our decision to study county-level voting patterns limits the number of observations in each regression. This restricts the number of explanatory variables we can explore. However, the number we use still compares favorably with previous studies; and as a practical matter, the coefficient estimates are sufficiently precise to attain statistical significance, and the explanatory power of the regressions is sizeable. We deliberately do not take cities as our unit of observations, as did Deacon and Shapiro [1975] and others, because this would make it difficult to study the behavior of voters employed in agricultural industries, and as shown below would thus fail to capture a central dimension of environmental demand.

${ }^{8}$ Like most studies, we do not address the problem that the set of voters are not a random sample of county residents. 


\section{Explanatory Variables}

Equation (1) is a typical demand equation except that the dependent variable is not the quantity of the good, but the log-of-the-odds of a favorable vote. To determine the effect of income, $\beta_{1}$, we use mean per capita county income in 1983 dollars for $I_{i}$. Both income and income-squared are included to allow the income effect to vary as people become richer. ${ }^{9}$

Because the price, $P_{i}$, is not directly observable, we include a vector of variables that are likely to be correlated with it. Seven price variables are considered. They were selected based on information culled from official election documents and articles in California Journal and the Los Angeles Times. In general, the "price" of a proposed increment of an environmental good to voters in a given county is the amount those voters would have to give up in order to supply the good. Perhaps the most plausible price, in this opportunity cost sense, is the income and employment that would be lost. For example, the price of increasing the supply of forest land is likely to be positively correlated with the amount of income a county derives from the timber industry. This reasoning suggests that the price of an initiative to a county may depend on the industrial makeup of its economy. Accordingly, four of our price variables are a county's per capita income from the construction, farming, forestry, and manufacturing industries. ${ }^{10}$ The cost of environmental goods extends into other industries as well if displaced workers can migrate, pushing down wages in their new industry. Workers in construction, farming, and forestry are less educated on average than other workers; if environmental legislation hurts these industries, then it also ultimately poses a threat to less-educated workers in all industries. To allow for this possibility, we include in the $P_{i}$ vector a variable equal to the fraction of a county's population with a college degree. ${ }^{11}$ The sixth price variable is the percentage of a county's population residing in a city, and the seventh is a dummy variable for the northern counties. As explained below, these last two variables capture differential costs in the provision of water- and park-related goods.

The variables included in the $P_{i}$ vector vary from initiative to initiative. Some degree of arbitrariness is unavoidable in deciding what variables to include in a particular regression. For two reasons we decided to err on the side of including too many rather than too few variables. First, we wanted to facilitate estimation of the income effect--exclusion of a relevant variable might bias the income coefficients but inclusion of an irrelevant variable will not. Second, in some cases we did not develop strong priors about what variables

\footnotetext{
${ }^{9}$ We estimated the regressions using linear and logarithmic specifications as well, but the best fit was achieved by the specification we report.

10 We tried using industry employment instead of income in the regressions and found similar results.

11 We also tried an education variable equal to the proportion of a county with a high school diploma, but the fit was inferior.
} 
were appropriate, and rather than take a stand we thought it would be better (and more informative) simply to let the data tell us. We followed several other selection rules. If an initiative seemed likely to have a differential impact on, or was sponsored or opposed by one of our four industries, that industry variable was included. When an initiative concerned water, three variables were included: farm income, city population, and the north dummy. This reflects the nature of California water politics which center around use of water from the Sacramento-San Joaquin Delta, and pit the water-rich north against the arid south, and urban users against irrigating farmers. ${ }^{12}$ The city and farming variables were also included whenever parks were involved because park expenditure often goes to municipalities (this explains the otherwise anomalous tendency for big city police chiefs to support park measures, which they view as a way to reduce crime by cleaning up deteriorating parks and playgrounds.) Education was included in all regressions because they all have some jobrelated impact. Our specific choice of price variables for each initiative is explained in the appendix.

The parameter $\beta_{3}$ indicates pure preference effects on the demand for environmental goods. As economists, we tend to favor price and income theories, and avoid explanations that rely on preferences, primarily for methodological reasons [Stigler and Becker, 1977]. The usefulness of this approach is ultimately founded on its empirical advantages. Voting on the environment seems to be a particularly appropriate arena to test the utility of a purely pricetheoretic approach because environmental demand (and particularly the political expression of this demand) is commonly attributed to preference variables such as ideology, political orientation, and the like. Whether people are "truly" motivated by preferences or prices and income is probably unknowable, but from a research perspective we can ask how much of observed behavior can be explained in terms of conventional economic concepts. We conduct two exercises to shed light on this question, motivated in part by analogous procedures in Peltzman [1984]. First, we estimate equation (1) under the assumption that $\beta_{3}=0$, and measure how much can be explained without reference to preference variables. Second, we introduce an explicitly political variable as $X_{i}$, Democratic party registration as a fraction of combined Democrats and Republicans, and measure how much explanatory power is gained by doing so. ${ }^{13}$

12 For example, see "Vital State Water Project in Fiscal Crisis Is Beset by Environmental Controversy," California Journal, February 1970; "Water: Where Do We Go From Here?," California Journal, September 1982; and "Water, Water: Does the State Need a New Way of Thinking about a Vital Resource?," California Journal, March 1988.

${ }^{13}$ In California, citizens register to vote in a particular party's primary. These are the numbers we use. 


\section{Data Sources}

Table 2 lists the explanatory variables and provides a precise description of each one. Vote totals and party registration numbers were drawn from California's official election returns, Statement of Vote, published by the California Secretary of State (Sacramento, CA). City population percentages were calculated from information in various years of California County Fact Book, published by County Supervisors Association of California (Sacramento, CA) and California Statistical Abstract, published by the California Secretary of State (Sacramento, CA). The rest of the data were taken from the 1993 version of the Regional Economic Information System CD-ROM, Bureau of Economic Analysis in the Department of Commerce (Washington, D.C.)

\section{Results}

Table 3 reports the parameter estimates, and beneath them in parentheses standard errors, for the 14 "pro-environment" initiatives. The table is organized so that each row presents the regression coefficients for the initiative indicated in the first column. The last column reports the $R^{2}$ and $\bar{R}^{2}$.

The collection of numbers in Table 3 is difficult to digest all at once, so below we analyze it in more bite-sized pieces. However, some broad characteristics of the estimates are apparent at this point. First, measured by $R^{2}$, the regressions seem to provide a good fit for the data. Every regression explains over half of the variation in county voting; eleven regressions explain over 60 percent of the variation, and seven explain over 70 percent. Second, the somewhat confining sample size of 57 observations does not appear to prevent achievement of precise coefficient estimates. For example, the income coefficients are statistically significant at the 10 percent level in 11 of 14 measures, and at least one industry variable is significant in all but two regressions.

\section{Income}

A central objective of this paper is to estimate the effect of income on the demand for environmental goods. Many people are convinced by introspection that the environment is a normal good, but as the brief survey in the introduction indicates, reliable statistical evidence in support of this belief is lacking. To make reliable estimates of the income effect requires that prices are held constant. The performance of the price proxies, industry, education, city population, and north, is thus encouraging.

Table 3 clearly shows that income matters for environmental voting. Moreover, the relationship between voting for environmental goods and income appears to be concave. 
Except for 1974-17, all coefficients reveal a concave relationship, and the estimates are statistically significant for 10 initiatives, including all of them since 1986. In itself, however, this does not tell us whether the environment is a normal or inferior good-concavity implies that it is normal for low enough incomes and inferior for high enough incomes.

We can assess whether the environment is a normal or inferior good at any given income level using the estimates in Table 3 . However, the estimates are only reliable for incomes that lie within the sample. Table 4 reports the minimum and maximum (county mean) income in the sample for each initiative. Except for 1972-9, the turning point in the relation falls within the sample distribution. Thus, the estimates appear to be telling us that environmental goods are inferior for some incomes within the sample. It also follows that we will not be able to conclude with statistical confidence that the environment is uniformly a normal or inferior good. We focus instead on measuring the income effect at two specific income levels, the (unweighted) mean level of income as seen in Table 2, and the maximum level of income. The former might be considered the "average" income effect, while the latter is the most likely to provide evidence of inferiority.

Column (1) of Table 4 reports the derivative of the log-of-the-odds with respect to income, evaluated at the mean level of income. Except for 1974-17, the point estimates indicate that the environment is a normal good. The next column reports the F-statistic for the hypothesis that the derivative is equal to zero. This is calculated in the usual way by imposing a linear restriction on the parameters. It is possible to reject the hypothesis that the derivative is equal to zero for 10 initiatives, and the estimate for $1982-13$ just escapes statistical significance. In square brackets beneath is another $F$-statistic, this one calculated from a pooled random effects model in which we impose the condition that the error variances are equal across initiatives. ${ }^{14}$ In theory, these estimates are more efficient. As can be seen, they give similar results: a statistically significant positive relation between income and voting for the environment is present for the same 10 initiatives.

Column (2) reports the derivative evaluated at the maximum level of income, and the corresponding $F$-statistics are in the subsequent column. According to the point estimates, the environment is an inferior good for high income people in 12 of 14 measures, and all of them since 1982. Most of these derivatives cannot be distinguished from zero at the 10 percent level, but six of them can using the regular $F$-statistic, and five based on the pooled statistic. ${ }^{15}$ Of the six measures that the wealthy viewed as inferior goods, a common

\footnotetext{
${ }^{14}$ We could not reject the hypothesis that this was true $(p=0.130)$.

15 To check whether these findings were a statistical artifact of our second-order specification, we also ran the regressions with splines that divided income into three groups. We found significant negative segments for the upper income group in the same six equations and several others.
} 
theme was the intent to increase provision of public spaces. For example, 1972-20 proposed to conserve coastal areas, 1988-70,1990-117,1990-128, and 1990-180 allocated funds for parks, forests, and recreation areas. It is probably incorrect to say that the rich view parks and their like as inferior goods. Instead, it may be that they can purchase these goods privately (in the form of a vacation, a vacation home, a private campground, and so on), and so view public provision of these goods as undesirable. This echoes the argument in Barzel [1973] that high income families might vote against an increase in public education because they have access to private schools. A similar argument may explain the inferiority of 1986-65, if the rich are more likely to purchase their drinking water privately (bottled water) than use tap water.

Pending future research, we should note that we cannot rule out the possibility income is proxying for price. According to this interpretation, the pieces of legislation under consideration contain a number of subtle and unmeasured (by us) details that impose disproportionate costs on the poorest and richest voters. We have no reason to accept this hypothesis, but if true it would provide additional confirmation for Director's Law [Stigler, 1970].

Table 4 also reports information from a set of regressions that include only income, income-squared, and a constant as explanatory variables. These regressions give reducedform estimates of the full effect of income. They are analogous to the estimates in Selden and Song [1994] and Grossman and Krueger [1995], but cover a wider range of issues, and are meant to suggest how environmental demand evolves in response to rising income. Column (3) reports the derivatives at the mean. For all initiatives, people with mean incomes are more likely to vote for the environment as their incomes rise. The derivatives are statistically significant at the 1 percent level for all but the bottle deposit measure. Column (4) reports the derivatives at the maximum. The pattern is mixed compared to that of column (2). The point estimates are positive in four cases and significantly so for $1982-11$ and 1994-185. Of the 10 negative coefficients, three of them can be statistically distinguished from zero, including two park and wildlife area measures.

\section{Prices}

The four industry variables, education, city population, and the north dummy are included to capture price effects on environmental demand. The main reason we include these variables is to isolate the income effect, but they are of some interest in their own right. Our conjecture is that an important cost of supplying environmental goods is a loss of income to individuals in particular occupations. Based on press accounts and other research, natural resource industries and manufacturing seem the most likely to suffer from environmental initiatives. 
The parameter estimates on the industry variables are consistent with this hypothesis. Construction counties showed a significant tendency to vote no on seven measures, five of which would have set aside undeveloped land. Farm counties supported only the bottle deposit measure that would have lowered their production costs, and voted significantly against 10 initiatives. Forestry counties also voted against measures that threatened their income; significant negative coefficients were found for 1972-20, 1988-70, 1990-117, 1990-130, and 1994-180, and insignificant negative coefficients for 1990-128 and 1994-185. Manufacturing counties had significant coefficients in opposition for seven measures. The general consistency with economic theory seen in Table 3 is not without exceptions. For example, it is puzzling that manufacturing counties were in favor of 1972-9.

Education is included to capture within-industry variations in economic impact from environmental initiatives. The coefficients on the industry variables indicate that the measures in our sample had adverse effects on the earnings of people employed in construction, farming, forestry, and manufacturing. If workers in these industries are less skilled than workers on average and labor is mobile, then less-skilled workers in all industries will experience an earnings decline. Consequently, less-educated workers in general will oppose environmental initiatives. In fact, Table 3 reports positive education coefficients for all but one measure, and statistically significant coefficients for 7 of 15 .

There are other price theoretic explanations for the education effect. A college education may lower the cost of accumulating "appreciation capital" for the environment in much the same way that music training is believed to develop human capital that increases demand for music [Stigler and Becker, 1977]. Education may reduce the cost of acquiring and evaluating information about initiatives [Matsusaka, 1995]. Voters who are confused about the consequences of a ballot proposition tend to vote against it [Magleby, 1984]. The education variable may pick up industry effects that slip through our broad classifications. Additional research is needed to identify exactly what price the education variable is capturing. ${ }^{16}$

City dwellers were more likely to vote in favor of the environment, and the effect is significant in six initiatives. One of these initiatives promised more water for cities (198213) and four provided funds for parks, many of which are located in urban areas.

The coefficient on the north dummy is always positive, and achieves statistical significance for eight initiatives. There does not seem to be a general reason for this, but rather a number of initiative-specific considerations, for example, the gill net ban off the coast of

\footnotetext{
16 There are also non-price theoretic explanations for the positive education effect. One could argue that the educated are more "enlightened" about the benefits of preserving the environment. Environmental organizations have long asserted that what separates them from the population at large is education about the issues; one of the purposes of the Sierra Club, according to its bylaws [Cohen, 1988: page 455] is "to educate and enlist humanity to protect and restore the quality of the natural and human environment."
} 
southern California (1990-132) and provision of public transit primarily in northern California (1994-185).

The price proxies reveal a stability in voting patterns across time and issues that is not predicted by theory. This suggests that environmental initiatives consistently impose the cost of providing environmental goods on the same groups, namely workers in the construction, farming, forestry, and manufacturing industries and less-educated workers in general. It could easily be done otherwise; for example, 1990-130 could have been written to include a subsidy to displaced timber workers financed by a tax on highly-educated workers such that the educated ended up bearing the costs of more forest land. Why environmental legislation so regularly allocates costs as it does is an open theoretical question, perhaps related to deadweight and transaction costs in redistributing income as suggested by Becker [1983], or perhaps natural resource industries are relatively strong in the state legislature, forcing relatively weaker interests to take their cases directly to the electorate. Further research is needed to untangle this.

\section{Counter-initiatives}

Table 5 presents regressions for the two counter-initiatives (1990-135, 1990-138). The table is analogous to Table 3. These regressions serve as checks on the interpretation of the results. In order to make inferences about demand from voting data, it must be true that voters have enough information to cast their vote for the outcome that is in their best interest. If voters understand their best interest, we expect to see certain patterns when comparing initiatives and counter-initiatives. The clearest case is 1990-130 and 1990-138. The first measure arguably proposed to increase the supply of forests while the counter-initiative proposed to decrease the supply. If citizens vote sincerely, then those who favored 1990-130 should have opposed 1990-138, and conversely. This suggests a mirror pattern in the coefficients like what is observed; each positive parameter estimate in 1990-130 is matched by a negative estimate in 1990-138, and conversely. The case of 1990-128 and 1990-135 is more complicated because 135 appeared to be a compromise between 1990-128 and the status quo. In California, when two conflicting measures each receive more than 50 percent of the vote, the one with the highest percentage takes effect. Thus, we do not have a clear prediction as far as the pattern. However, insofar as 1990-135 tended to be viewed as a close substitute for the status quo, the approximate mirroring that is seen is reasonable.

\section{Economics and Ideology}

The environment is often held to be beyond the scope of economics, its demand driven by phenomena such as ideology and politics. As economists, we hesitate to assign causal 
roles to such phenomena, preferring instead to delve into price and income effects. One of the objectives of this paper is to see how well the environment can be understood as a conventional economic good, that is, without introducing non-economic preference variables. We to address this issue in statistical terms, by measuring the ability of income and our fairly crude price proxies to explain environmental voting. In this respect, Table 3 provides broad support for an economic approach. As measured by $R^{2}$, price and income can account for a remarkable amount of variation in county voting. Indeed, it is doubtful that demand estimates for traditional goods would produce markedly better fits.

Our purpose here should not be misunderstood. There may be ideological variables with equally impressive explanatory power. For example, it may be possible to explain a person's environmental voting by his position on a liberal-conservative spectrum. However, as economists we are inclined to push in the direction of price and income effects as long as that seems productive. The underlying methodological position was described by Peltzman [1984] with a hypothetical example (page 192).

Suppose an economist initially seeks to explain auto purchases with two variablesprice and party registration-and finds that party is clearly the more important of the two variables. An economist, unlike a sociologist or a political scientist, would probably suspect that party is simply a proxy for income. Now, suppose an ordinary price-cum-income demand relationship explains the data about as well as price-cum-party, but that party provides some small marginal explanatory power. This result would sooner lead the economist to elaborate the role of income (or price) than to undertake serious analysis of the role of party preference on durable goods purchases. Had the ordinary demand function failed utterly to reduce the plausible role of political preference, some pessimism about the future of economic versus sociological analysis of car buying would be warranted.

In short, if we find that it is possible to explain environmental voting with variables plausibly related to price and income, then there is some justification for continuing to refine and elaborate the economic approach. If the price and income approach fails to organize the data, then ideological or political approaches would be called for. ${ }^{17}$

The high $R^{2}$ 's provide key support for the utility of an economic approach. This makes it important to be sure that they are not statistical flukes. In particular, we need to be concerned about the possibility of multicollinearity because high $R^{2}$ 's are a textbook symptom of this problem. It turns out that income and education are highly correlated; the correlation

17 For an interesting example of the opposite approach, see Poole and Rosenthal [1993]. 
between them is 0.7 in 1972 and rises to 0.9 in 1994 . None of the remaining variables show significant pairwise collinearity.

The most direct way to determine if multicollinearity is driving up the $R^{2}$ 's is to reestimate the regressions without the collinear variables and see if the $R^{2}$ 's become small. We do not know exactly what variables might be causing a problem, so we perform the exercise in several ways. Three sets of regressions were estimated. The first set included only income and income-squared as explanatory variables; the second included only the three industry variables, and the third included only education (all regressions had constants.)

Table 6 contains the $R^{2}$ 's and in parentheses $\bar{R}^{2}$ 's that result. Each row corresponds to an initiative, while the bottom row, labeled "Combined" is the explained sum of squares for all initiatives divided by the total sum of squares for all initiatives. For reference, column (1) reproduces the $R^{2}$ 's from the full regressions in Table 3. Column (2) reports the $R^{2}$ 's when the only explanatory variables are those for income. It can be seen that income alone accounts for over 60 percent of the variation in county voting for the water conservation and gill nets measures, over 50 percent of the variation for four other initiatives, and over 40 percent for 10 initiatives in all. Column (3) reports the $R^{2}$ 's for regressions in which the exogenous variables are construction, farm, forestry, and manufacturing income. These industry variables alone generally perform worse than income, but there are exceptions. They can explain over 60 percent of behavior on the counter-initiative to Proposition 128, with farm income carrying most of the load. The occupation regressions also fit well on 1972-9, 1982-13, 1988-105, and 1990-117. Column (4) presents the $R^{2}$ 's from regressions in which the independent variable is education. These regressions can account for over 60 percent of the variation on the gill nets and public transit measures, over 50 percent on the water conservation initiative, and over 40 percent on four others. Taken together, the evidence suggests that for most initiatives, the $R^{2}$ 's reflect a true ability of price and income to explain voting variation, not multicollinearity. ${ }^{18}$ It seems appropriate to conclude that a conventional economic demand-theoretic approach can in fact explain most of the variation in county voting on environmental goods.

Although the full regressions appear to fit the data well, a non-trivial amount of crosssectional variation remains to be explained. This residual may be explicable by the coarseness of our price proxies. However, it may also be driven by ideological factors. The fact that economic variables can explain the bulk of environmental voting does not rule out a marginal role for ideology.

We provide one assessment of the possibility of such a role by re-estimating the complete

18 This conclusion is also buttressed by the fact that the regressions do not seem to suffer from another textbook symptom of multicollinearity, large standard errors. 
regressions in Table 3 and adding an ideology variable. The variable we choose, largely for accessibility reasons, is the number of registered Democrats divided by Democrats and Republicans. Political parties typically are believed to represent different ideologies. The component of party membership that is determined by income and occupation is controlled by those variables in the regression. To the extent that there is an independent component of ideology that influences environmental voting, that is, a component that is not induced by economic factors, it should be seen in the coefficient on the party variable.

We report the $R^{2}$ 's from these party-augmented regressions in column (5). ${ }^{19}$ Column (6) reports the difference between column (5) and column (1). This indicates how much additional explanatory power is added to the regression by considering party affiliation.

As it turns out, the usefulness of the party variable varies across initiatives. At one extreme, the party variable increases the explanatory power of the "Big Green" equation by more than 20 percent; it increases the $R^{2}$ by more than 15 percent for seven other initiatives. On the other hand, it adds only 1.8 percent to the Mountain Lion initiative, and less than 10 percent to five other measures. Over all 16 initiatives, party adds a little over 0.128 to the $R^{2}$ on average. Thus, while price and income can explain most of the variation, it seems that party can be useful in explaining some of the residual variation. Whether the increased $R^{2}$ 's are caused by party proxying for unmeasured prices or ideology cannot be determined here.

There is still variation to be explained after including the party variable. Party membership is one measure of ideology. We might wonder if the unexplained variation is due to unmeasured ideological factors. In order to get a sense of how likely a possibility this is, Table 7 reports the correlation in county residuals across the 16 measures. These are the residuals from the regressions that include party membership. If a latent variable is present, we expect to see a positive correlation in residuals across the pro-environment initiatives and a negative correlation with the counter-initiatives. This is a weak test because the presence of correlation could be evidence of an unmeasured non-ideological variable, but it has some power in that the absence of the expected correlations would be problematic for the ideology interpretation.

Whether Table 7 supports the latent variable hypothesis is perhaps in the eye of the beholder. Considering only the pro-environment measures, a simple count reveals that 75 of 91 correlations are positive, but only 20 are greater than 0.50 . The average is 0.26 . The

19 The Democrats coefficient is positive in all but the counter-initiative regressions. It is statistically significant at better than the 10 percent level for all initiatives but 1974-14. The parameter estimates on the other coefficients are similar to those reported in Table 3. The main difference is that the north dummy reverses sign in seven cases. 
largest correlations are between the 1990 initiatives. The residual correlation between the pro-environment measures and the counter-initiatives is positive in 14 of 28 cases, with an average of -0.001 . One can take the correlations as supporting an ideology interpretation for the residual variance, but the strength of the effect is not overwhelming, and it is equally plausible to hypothesize that there is an unmeasured latent price variable. We shall leave it to the reader to draw his or her own conclusion.

The results is this section are somewhat related to the vast literature on shirking and ideology in legislatures (see the special June 1993 issue of Public Choice for an overview.) The literature has focused on two questions: (1) do legislators represent constituent interests, and (2) do constituent interests have an ideological as well as conventional economic component? Our paper has nothing to say about the first question, but there is strong evidence that legislators by and large vote their constituents' interests [Lott and Davis, 1992; Lott and Bronars, 1993]. It remains an open question, however, to what extent these interests include ideology. There are a number of suggestive studies showing that interest group ratings predict roll call votes, but virtually no compelling direct evidence that ideology is an important part of constituent interests. For example, Kau and Rubin [1993] estimate a regression showing that congressmen who vote conservatively receive more votes when they run in a conservative district, as measured by the district's vote for Ronald Reagan in the 1980 presidential election; but they do not report the marginal explanatory power of this variable relative to their measures of constituent economic interests. We do not have a general answer to the second question, but our results suggest that ideological motivations take a back seat to economic interests for most voters when it comes to environmental legislation.

\section{Conclusion}

The purpose of this paper is to apply conventional economic analysis to the study of environmental demand. We estimate cross-county voting regressions for 16 environmental initiatives in the state of California between 1970 and 1994. These initiatives concerned a wide variety of issues. The explanatory variables in each regression are income and seven variables that are plausibly correlated with the anticipated pecuniary costs of the proposed measures. We focus on ballot propositions as a way to avoid the well-known limitations of other techniques commonly used to study environmental demand, such as contingent valuation and hedonic pricing.

Across a wide range of issues, the environment appears to be a normal good for people with mean levels of income. However, certain environmental goods, particularly parklands, appear to be inferior goods for people with high income levels. This may be because the 
wealthy are able to purchase such goods privately, and thus do not favor increased public provision. The estimates also suggest that the "price" of increased provision of environmental amenities is paid by people employed in natural resource industries such as farming and forestry, and by less-educated workers in general. Those people who do not bear the cost, apparently workers in jobs requiring high levels of education, consequently are more likely to favor increased provision of environmental goods.

The estimates sketch a picture of the political economy of the environment by identifying the economic interests that are at stake. Pressure groups play a central role in the economic theory of regulation as developed by Stigler [1971], Peltzman [1976], and Becker [1983]. Our estimates indicate which groups are important, and suggest that they are somewhat stable across time and issues. Thus, it may be sensible to speak of an environmental "movement" in the sense of a general demand for environmental goods, or a stable coalition of groups pushing for increased environmental amenities.

Finally, our estimates address the broader issue of whether economics is an appropriate way to study environmental demand. It is sometimes argued that economics does not apply to the environment, that ideology and politics are the dominant factors. We show that a small set of purely economic variables can account for the majority of the variance in county voting patterns. Furthermore, inclusion of a variable representing political ideology adds a relatively small amount of explanatory power to the regressions. Whether or not people are "truly" motivated by ideology is beyond the scope of this paper, but our results suggest that little is lost by studying environmental demand as if it were any other economic good, that is, by focusing on price and income effects. 


\section{Appendix. Content of Initiatives}

\section{June 1972. Proposition 9-Pollution omnibus}

This proposition was the most sweeping piece of environmental legislation proposed up to that time, and has been called the first environmental initiative [Lutrin and Settle, 1975]. It provided for removal of lead from gasoline sold in the state, authorization for the state to close businesses that violated air pollution standards, banning of certain pesticides (DDT, DDD, chlordane), limits on diesel fuel, a five year ban on construction of nuclear power plants, and a ban on new offshore oil drilling. The legislative analyst estimated the cost of the measure to be between $\$ 200$ million and $\$ 770$ million over 30 years from lost offshore lease revenues, and $\$ 5$ million per year from onshore revenues. The initiative was sponsored by the People's Lobby and Ralph Nader; it was opposed by oil companies, utilities, Teamsters, and the California Manufacturers Association. Most environmental organizations, including the Sierra Club and Audubon Society, remained neutral.

PRICES-Pesticide restrictions would hurt farmers, and air quality standards, gasoline reformulation, and pesticide regulations would hurt manufacturers.

\section{November 1972. Proposition 20-Coastal zone conservation}

This measure proposed to create six regional coastal zone commissions and a state commission, shift jurisdiction over coastal development from local governments to the commissions, and severely restrict coastal development for three years while the commissions formulated master plans. The legislative analyst predicted a cost to taxpayers of $\$ 1.25$ million per year. The measure was supported by the California Coastal Alliance, Planning and Conservation League, Sierra Club, League of Women Voters, University of California student government, National Council of Senior Citizens. It was opposed by the California Chamber of Commerce, California Manufacturers Association, California Real Estate Association, Teamsters, and other building, construction, and fishermen organizations.

PRICES-Development restrictions would hurt the construction industry, forestry workers might be hurt if logging restrictions were adopted, and manufacturers were listed as an opposition group. Northern interests might be favored by the transfer of development control away from state government, to the extent that southern interests were relatively influential in the capital. Likewise, farmers might lose if they were relatively influential in the state government.

\section{November 1974. Proposition 17-Stanislaus River protection}

This measure called for a halt in construction of the New Melones Dam on the Stanislaus River near Yosemite Park. The purpose of the dam was to store irrigation water and produce electricity. Because the dam was a federal project, the initiative was advisory, but it was expected that the project would be cancelled if a majority voted yes. The most visible supporters were a collection of conservation groups that wanted to preserve the river for white-water recreation; opponents included the Army Corps of Engineers.

PRICES-Water rights involve the conflicting claims of farmers and city-dwellers, north and south.

\section{November 1982. Proposition 11-Bottle deposit}

This statute mandated a five cent refund on all beer and soft drink containers sold in the state. It was supported by the Sierra Club, consumer groups, the Teamsters, the Retail Clerks Union, and the California Farm Bureau Federation (over concern about damage to tractor tires and the cost of cleaning rural litter), and opposed by brewers and soda pop companies, glass and can container manufacturers, and the California Grocers Association.

PRICES-Farmers were on record in support and manufacturers were on record against; north-south differences might reflect a greater spread of the private and public recycling industry in the north. 
November 1982. Proposition 13-Water conservation

This statute proposed new water conservation standards, and contained sections to protect streams and lakes, and impede the use of the New Melones Dam. The measure was expected to have the greatest impact on farmers, by forcing them to conserve water. It was supported by conservation groups, who argued that the measure would create jobs by using water more efficiently and encouraging construction of water conservation facilities. It was opposed by the Agricultural Council, California Farm Bureau, Western Growers Association, Cattleman's Association, California Chamber of Commerce, and water agencies.

PRICES-The construction industry stood to benefit from creation of new jobs; farmers were on record in opposition; manufacturers might win or lose depending on the extent of their business with the construction and farm industries; water involves cities and regional interests.

November 1986. Proposition 65-Toxic disclosure

This statute aimed to prohibit businesses from releasing chemicals that cause cancer or reproductive disorders into sources of drinking water, and required businesses to warn customers about potentially toxic chemicals in their products. Public agencies, such as power plants, sewage systems, and water systems, were exempted from the requirements. Farmers were concerned that certain fertilizers and pesticides would be banned, and they would be forced to prove that others did not cause cancer. Manufacturers were concerned about the cost of labeling products. The measure was supported by environmental organizations, and opposed by the oil, chemical, and agriculture industries.

PRICES-Farmers and manufacturers were on record in opposition; public agencies, typically in cities, were exempted.

June 1988. Proposition 70-Park bonds

This statute authorized a $\$ 776$ million bond issue to acquire wildlife and park lands, and develop, rehabilitate, protect, and restore existing park lands. It was supported by the Planning and Conservation League and other conservation organizations. Opposition included the California Farm Bureau Federation. Rural interests were concerned that over 90 percent of the money could be spent on new acquisitions, particularly for parks in cities. Opponents also complained that the measure earmarked specific expenditures to satisfy special interests.

PRICES-Construction and manufacturing industries might be hurt by development restrictions; farmers were on record in opposition; costs might rise in the timber industry as forest land is taken out of production; expenditure for city parks benefits urban-dwellers; the regional dummy might capture northsouth variations in earmarked funds.

November 1988. Proposition 105-Toxic disclosure

The main environmental feature of this initiative was a requirement that businesses warn the public if their consumer products were toxic. It also required insurance companies to disclose certain information about their policies in relation to Medicare, required nursing homes to disclose to their consumers certain information about past care, contained clauses to make it clear which groups were sponsoring political campaigns, and required companies to disclose if they did business in South Africa. The measure was supported by a coalition of consumer groups, environmentalists, and senior citizens under the name of Consumers United for Reform (CURE). Organized opposition was minimal.

PRICES-The construction, farming, and manufacturing industries might be adversely impacted by toxic disclosure regulations.

June 1990. Proposition 117-Mountain lion protection

This proposition banned the hunting of mountain lions, created a fund to acquire and restore wildlife areas and wetlands, and allocated $\$ 30$ million a year to the fund for 30 years. The money was to be drawn from 
existing tobacco tax revenues. Purchases were specifically designated for the Santa Monica mountains, Santa Lucia mountains near Monterey city, Lake Tahoe, and coastal conservation. The measure was supported by the Planning and Conservation League and other conservation groups. It was officially opposed by the San Joaquin Chapter of the Wildlife Society on the grounds that it would divert envirommental resources from truly needy programs, and by sportsmen who disputed how many lions were left.

PRICES-The costs of this measure arose from the wildlife and wetlands funds, not preservation of the mountain lions per se; the issues are then similar to those for 1988-70.

\section{November 1990. Proposition 128- "Big Green"}

The feature of this proposition that received the most attention was a ban on the use of pesticides that cause cancer or reproductive harm. The legislative analyst estimated this would eliminate 350 out of the 2,300 chemicals in use. The measure also proposed to reduce the emission of greenhouse gases by 40 percent (it did not specify how), provided for $\$ 300$ million in bonds to buy redwoods, prohibited new offshore oil drilling, tightened water quality standards, and established an elected state Environmental Advocate. The total cost to all levels of government was estimated by the legislative analyst to be about $\$ 110$ million per year. The initiative was supported by environmental groups, including the Sierra Club, National Wildlife Federation, California League of Conservation Voters, and Natural Resources Defense Council. It was opposed by the chemical, oil, timber, and agriculture industries as well as the California Taxpayers Association, California Chamber of Commerce, and California Manufacturers Association.

PRICES-This measure affected pesticides, water, and parks, and thus involved the entire range of interests.

November 1990. Proposition 130-Forest preservation

The main features of this measure were a ban on clear-cutting of forests, authorization of a $\$ 742$ million bond issue to purchase old-growth redwood forests (especially Headwaters Grove in northern coastal California), and restriction of industry membership on the state Board of Forestry that regulates logging. The legislative analyst estimated it would cost $\$ 55$ million per year for 20 years to repay the bonds. The proposition was supported by a coalition of environmental groups and opposed by the timber industry.

PRICES-The construction industry might be hurt by rising wood prices, and the farming, forestry, and manufacturing industries were officially opposed; none of the restrictions would apply in urban areas; and the north dummy might pick up the fact that the redwoods are concentrated in the northern part of the state.

\section{November 1990. Proposition 132-Gill net ban}

This measure proposed to ban the use of gill nets for commercial fishing. At the time of the election, gill net fishing was already prohibited along the coast of Northern California. It was supported by sports fishermen and conservation groups who disliked the indiscriminate nature of gill net fishing, which occasionally kills dolphins and other marine animals. It was opposed by commercial fishers and fish processors who argued it would cost jobs in food manufacturing.

PRICES-Manufacturers were threatened with lost jobs; the ban would make a difference only off the coast of southern California.

\section{November 1990. Proposition 135-Counter-initiative to 128}

This measure proposed to increase the state's monitoring of pesticide residuals on food and require the state to collect and dispose of pesticides that could not be used; the cost of both services was to be shifted to the state from the processors. The legislative analyst estimated start-up costs of $\$ 35$ million and annual costs between $\$ 7$ and $\$ 13.5$ million. The initiative was supported by agriculture, food processors, and grocers, and 
opposed by environmental groups including the Sierra Club, California League of Conservation Voters, and Natural Resources Defense Council.

PRICES-Farmers, pesticide and food manufacturers stood to gain from the pesticide regulations.

November 1990. Proposition 138 - Counter-initiative to 130

This measure proposed to modify the way the state granted logging permits, generally to the advantage of timber companies, prohibit the state from forcing sale of forests for 10 years, and called for but did not authorize a $\$ 300$ million bond issue for forest restoration. The legislative analyst estimated the bonds would cost $\$ 22$ million per year for 20 years. This initiative had the form of a restriction on clear-cutting, but in effect would have made such logging easier; effectively it would have nullified Proposition 130 if it received more votes. It was supported by the timber industry and opposed by most environmental groups including the Sierra Club, Audubon Society, Natural Resources Defense Council, Planning and Conservation League, and Defenders of Wildlife.

PRICES-This involved the same interests as 1990-130.

\section{June 1994. Proposition 180-Park bonds}

This measure authorized a bond issuance of nearly $\$ 2$ billion. The money would be spent to acquire, develop, and conserve park lands, historic sites, and wildlife and natural areas. It was similar to Proposition 170 on the 1988 ballot. The initiative was supported by the National Audobon Society, California Nature Conservancy, California Park and Recreation Society, Planning and Conservation League, and Save the Redwoods League. It was also supported by the police chief of Los Angeles and other law enforcement organizations who argued that higher spending on parks would make urban neighborhoods safer. The main opposition was taxpayer groups.

PRICES-This involved the same interests as 1988-70.

November 1994. Proposition 1985-Public transportation, gas tax

This initiative proposed to increase the gas tax by 4 percent. The proceeds would be used for electric rail and clean buses, light rail, commuter and intercity rail systems and wetlands, riparian habitat and parks. Priority was given to high speed rail along the Los Angeles-San Francisco corridors, and transit services in the Yosemite and Lake Tahoe areas. The measure was sponsored by the Planning and Conservation. League, who also sponsored Proposition 180 on the June 1994 ballot. Its supporters included the Congress of California Seniors, the Coalition for Clean Air, Citizens for Reliable and Safe Highways, and the California Public Interest Research Group. Opponents included various taxpayer groups and members of the California Transportation Commission, the California Highway Users Conference, and the California Business Alliance.

PRICES - The construction and manufacturing industries might be hurt by reductions in highway construction; public transit would be used by city-dwellers and not farmers; the projects were concentrated in the north. 


\section{References}

Barzel, Yoram, "Private Schools and Public School Finance," Journal of Political Economy, January/February 1973, 81, 174-186.

Becker, Gary S., "A Theory of Competition Among Pressure Groups for Political Influence," Quarterly Journal of Economics, August 1983, XCVIII, 371-400.

Blomquist, Glenn C., Mark C. Berger, and John P. Hoehn, "New Estimates of Quality of Life in Urban Areas," American Economic Review, March 1988, LXXVIII, 89-107.

Cohen, Michael P., The History of the Sierra Club, 1892-1970, San Francisco, CA: Sierra Club Books, 1988.

Coursey, Don, "The Demand for Environmental Quality," The University of Chicago, December 1992.

Deacon, Robert and Perry Shapiro, "Private Preference for Collective Goods Revealed Through Voting on Referenda," American Economic Review, December 1975, LXV, 943955.

Diamond, Peter A. and Jerry A. Hausman, "Contingent Valuation: Is Some Number Better than No Number," Journal of Economic Perspectives, Fall 1994, VIII, 45-64.

Dubin, Jeffrey A., D. Roderick Kiewiet, and Charles Noussair, "Voting on Growth Control Measures: Preferences and Strategies," Economics and Politics, July 1992, IV, 191-213.

Filer, John E. and Lawrence W. Kenny, "Voter Reaction to City-County Consolidation Referenda," Journal of Law and Economics, April 1980, XXIII, 179-190.

Fischel, William A., "Determinants of Voting on Environmental Quality: A Study of a New Hampshire Pulp Mill Referendum," Journal of Environmental Economics and Management, June 1979, VI, 107-118.

Grossman, Gene M. and Alan B. Krueger, "Economic Growth and the Environment," Quarterly Journal of Economics, May 1995, CX, 353-377.

Hausman, Jerry A., editor, Contingent Valuation: A Critical Assessment, Amsterdam: North-Holland Press, 1993.

Kalt, Joseph P. and Mark A. Zupan, "Capture and Ideology in the Economic Theory of Politics," American Economic Review, June 1984, LXXIV, 279-300.

Kau, James B. and Paul H. Rubin, "Ideology, Voting, and Shirking," Public Choice, June 1993, LXXVI, 151-172. 
Lott, John R., Jr. and Michael L. Davis, "A Critical Review and an Extension of the Political Shirking Literature," Public Choice, December 1992, LXXIV, 461-484.

Lott, John R., Jr. and Stephen G. Bronars, "Time Series Evidence on Shirking in the U.S. House of Representatives," Public Choice, June 1993, VLXXVI, 125-149.

Lutrin, Carl E. and Allen K. Settle, "The Public and Ecology: The Role of Initiatives in California's Environmental Politics," Western Political Quarterly, June 1975, XXVIII, $352-371$.

Maddala, G. S., Limited Dependent and Qualitative Variables in Econometrics, Cambridge, UK: Cambridge University Press, 1983.

Magleby, David B., Direct Legislation, Baltimore, MD: Johns Hopkins University Press, 1984 .

Matsusaka, John G., "Economics of Direct Legislation," Quarterly Journal of Economics, May 1992, CVII, 541-571.

Matsusaka, John G., "Explaining Voter Turnout Patterns: An Information Theory," Public Choice, July 1995, LXXXIV, 91-117.

Mitchell, Robert Cameron and Richard T. Carson, Using Surveys to Value Public Goods: The Contingent Valuation Method, Washington, D.C.: Resources for the Future, 1989.

Pashigian, B. Peter, "Environmental Regulation: Whose Self-Interests Are Being Protected?," Economic Inquiry, 1985, XXIII, 551-584.

Peltzman, Sam, "Toward a More General Theory of Regulation," Journal of Law and Economics, August 1976, XIX, 211-240.

Peltzman, Sam, "Constituent Interests and Congressional Voting," Journal of Law and Economics, April 1984, XXVII, 181-210.

Poole, Keith T. and Howard Rosenthal, "The Enduring Nineteenth Century Battle for Economic Regulation," Journal of Law and Economics, October 1993, XXXVI, 837-860.

Schroeder, Larry D. and David L. Sjoquist, "The Rational Voter: An Analysis of Two Atlanta Referenda on Rapid Transit," Public Choice, 1978, XXXIII, 27-44.

Selden, Thomas M. and Daqing Song, "Environmental Quality and Development: Is There a Kuznets Curve for Air Pollution Emissions?," Journal of Environmental Economics and Management, September 1994, XXVII, 147-162.

Stigler, George J., "Director's Law of Public Income Redistribution," Journal of Law and Economics, April 1970, XXIII, 1-10. 
Stigler, George J., "The Theory of Economic Regulation," Bell Journal of Economics and Management Science, Spring 1971, II, 3-21.

Stigler, George J. and Gary S. Becker, "De Gustibus Non Est Disputandum," American Economic Review, March 1977, LXVII, 76-90. 
Table 1. California environmental initiatives, 1970-1994

\begin{tabular}{|c|c|c|c|c|c|}
\hline Proposition & & $\begin{array}{l}\text { Total } \\
\text { votes, } \\
\text { yes } \%\end{array}$ & $\begin{array}{l}\text { Number of } \\
\text { counties } \\
\text { in favor }\end{array}$ & $\begin{array}{c}\text { Least } \\
\text { favorable } \\
\text { county, } \\
\text { yes } \%\end{array}$ & $\begin{array}{c}\text { Most } \\
\text { favorable } \\
\text { county, } \\
\text { yes } \%\end{array}$ \\
\hline $1972-9^{p}$ & Pollution omnibus & 35.3 & 0 & 15.8 & 44.2 \\
\hline $1972-20$ & Coastal zone conservation & 55.2 & 31 & 17.4 & 70.4 \\
\hline $1974-17$ & Stanislaus River protection & 47.1 & 12 & 17.3 & 65.1 \\
\hline $1982-11$ & Bottle deposit & 44.1 & 15 & 29.0 & 62.2 \\
\hline $1982-13$ & Water conservation & 35.2 & 2 & 9.5 & 63.0 \\
\hline $1986-65$ & Toxic disclosure & 62.6 & 45 & 32.7 & 78.3 \\
\hline $1988-70^{p}$ & Park bonds & 65.1 & 40 & 25.8 & 74.9 \\
\hline $1988-105$ & Toxic disclosure & 54.5 & 25 & 32.9 & 64.4 \\
\hline $1990-117^{p}$ & Mountain lion protection & 52.4 & 17 & 19.0 & 67.8 \\
\hline $1990-128$ & "Big Green" (pesticides) & 35.6 & 1 & 12.2 & 62.0 \\
\hline $1990-130$ & Forest preservation & 47.9 & 10 & 15.3 & 70.7 \\
\hline $1990-132$ & Gill net ban & 55.8 & 32 & 28.2 & 77.3 \\
\hline $1990-135$ & Counter-initiative to 128 & 30.4 & 2 & 24.6 & 52.6 \\
\hline $1990-138$ & Counter-initiative to 130 & 28.8 & 0 & 19.7 & 48.9 \\
\hline $1994-180^{p}$ & Park bonds & 43.3 & 6 & 15.1 & 66.9 \\
\hline $1994-185$ & Public transit, gas tax & 19.5 & 0 & 5.3 & 49.7 \\
\hline
\end{tabular}

Note. Each proposition is identified by the year it appeared on the ballot, its official number, and a short description; a superscript $p$ after the number indicates that the initiative appeared on the primary election ballot rather than the general election ballot. For example, the first proposition appeared on the 1972 primary election ballot and was designated number 9. "Total votes, yes \%" is the number of yes votes divided by the sum of yes and no votes. "Number of counties in favor" is the number of counties in which the number of yes votes exceeded the number of no votes. There are 58 counties. 
Table 2. Summary statistics and definitions of dependent variables

\begin{tabular}{|c|c|c|c|c|c|c|c|c|c|}
\hline \multirow[b]{2}{*}{ Year } & \multirow[b]{2}{*}{ Income } & \multirow[b]{2}{*}{ Constr'n } & \multirow[b]{2}{*}{ Farming } & \multirow[b]{2}{*}{ Forestry } & \multirow[b]{2}{*}{ Manuf'g } & \multirow[b]{2}{*}{ Education } & \multirow[b]{2}{*}{ City } & \multicolumn{2}{|c|}{ Democrats } \\
\hline & & & & & & & & Primary & General \\
\hline 1972 & $\begin{array}{l}11.6 \\
(1.7)\end{array}$ & $\begin{array}{c}0.53 \\
(0.26)\end{array}$ & $\begin{array}{c}0.84 \\
(1.28)\end{array}$ & $\begin{array}{c}0.010 \\
(0.034)\end{array}$ & $\begin{array}{l}1.25 \\
(0.88)\end{array}$ & $\begin{array}{l}0.11 \\
(0.04)\end{array}$ & $\begin{array}{c}0.48 \\
(0.24)\end{array}$ & $\begin{array}{c}0.60 \\
(0.05)\end{array}$ & $\begin{array}{c}0.61 \\
(0.05)\end{array}$ \\
\hline 1974 & $\begin{array}{c}12.2 \\
(2.4)\end{array}$ & $\begin{array}{c}0.50 \\
(0.22)\end{array}$ & $\begin{array}{c}1.31 \\
(2.35)\end{array}$ & $\begin{array}{l}0.012 \\
(0.040)\end{array}$ & $\begin{array}{c}1.23 \\
(0.83)\end{array}$ & $\begin{array}{c}0.11 \\
(0.04)\end{array}$ & $\begin{array}{c}0.48 \\
(0.24)\end{array}$ & & $\begin{array}{c}0.61 \\
(0.05)\end{array}$ \\
\hline 1982 & $\begin{array}{l}12.0 \\
(2.5)\end{array}$ & $\begin{array}{c}0.42 \\
(0.25)\end{array}$ & $\begin{array}{c}0.52 \\
(0.66)\end{array}$ & $\begin{array}{c}0.001 \\
(0.003)\end{array}$ & $\begin{array}{c}1.03 \\
(0.90)\end{array}$ & $\begin{array}{c}0.16 \\
(0.06)\end{array}$ & $\begin{array}{c}0.49 \\
(0.26)\end{array}$ & $\cdots$ & $\begin{array}{c}0.59 \\
(0.06)\end{array}$ \\
\hline 1986 & $\begin{array}{l}13.4 \\
(3.1)\end{array}$ & $\begin{array}{c}0.67 \\
(0.32)\end{array}$ & $\begin{array}{c}0.41 \\
(0.53)\end{array}$ & $\begin{array}{c}0.014 \\
(0.057)\end{array}$ & $\begin{array}{c}1.19 \\
(0.99)\end{array}$ & $\begin{array}{c}0.19 \\
(0.08)\end{array}$ & $\begin{array}{c}0.51 \\
(0.25)\end{array}$ & $\cdots$ & $\begin{array}{c}0.57 \\
(0.07)\end{array}$ \\
\hline 1988 & $\begin{array}{l}13.6 \\
(3.3)\end{array}$ & $\begin{array}{c}0.70 \\
(0.35)\end{array}$ & $\begin{array}{c}0.54 \\
(0.77)\end{array}$ & $\begin{array}{c}0.001 \\
(0.002)\end{array}$ & $\begin{array}{c}1.21 \\
(1.00)\end{array}$ & $\begin{array}{c}0.19 \\
(0.08)\end{array}$ & $\begin{array}{c}0.52 \\
(0.26)\end{array}$ & $\begin{array}{c}0.57 \\
(0.07)\end{array}$ & $\begin{array}{c}0.56 \\
(0.07)\end{array}$ \\
\hline 1990 & $\begin{array}{l}13.8 \\
(3.4)\end{array}$ & $\begin{array}{c}0.71 \\
(0.35)\end{array}$ & $\begin{array}{c}0.46 \\
(0.71)\end{array}$ & $\begin{array}{c}0.006 \\
(0.016)\end{array}$ & $\begin{array}{l}1.14 \\
(0.98)\end{array}$ & $\begin{array}{c}0.19 \\
(0.08)\end{array}$ & $\begin{array}{c}0.52 \\
(0.26)\end{array}$ & $\begin{array}{c}0.55 \\
(0.07)\end{array}$ & $\begin{array}{c}0.55 \\
(0.07)\end{array}$ \\
\hline 1994 & $\begin{array}{l}13.4 \\
(3.3)\end{array}$ & $\begin{array}{c}0.60 \\
(0.26)\end{array}$ & $\begin{array}{c}0.37 \\
(0.57)\end{array}$ & $\begin{array}{c}0.006 \\
(0.016)\end{array}$ & $\begin{array}{c}1.07 \\
(0.93)\end{array}$ & $\begin{array}{c}0.19 \\
(0.08)\end{array}$ & $\begin{array}{c}0.54 \\
(0.27)\end{array}$ & $\begin{array}{c}0.55 \\
(0.08)\end{array}$ & $\begin{array}{c}0.55 \\
(0.08)\end{array}$ \\
\hline
\end{tabular}

Note. The main cell entry is the mean; standard errors are in parentheses. Statistics are computed over 57 observations (omitting Alpine). The 1994 regressions use personal and industry income numbers from 1992.

Income. Per capita annual county income in thousands of 1983 dollars.

Construction, Farming, Forestry, Manufacturing. Per capita annual county income from the indicated industry in thousands of 1983 dollars.

Education. Fraction of county population with 16 or more years of education; 1970 census numbers are used for 1972 and 1974, 1980 census numbers are used for 1982, and 1990 census numbers are used otherwise.

City. Fraction of county population residing in a city as opposed to an unincorporated area as of January 1 , except for 1972 which is as of April 1.

Democrats. Number of citizens registered to vote in Democratic party primary as a fraction of registered Democrats and Republicans.

North. Dummy variable equal to 1 for all counties but Imperial, Kern, Los Angeles, Orange, Riverside, San Bernardino, San Luis Obispo, San Diego, Santa Barbara, and Ventura. 


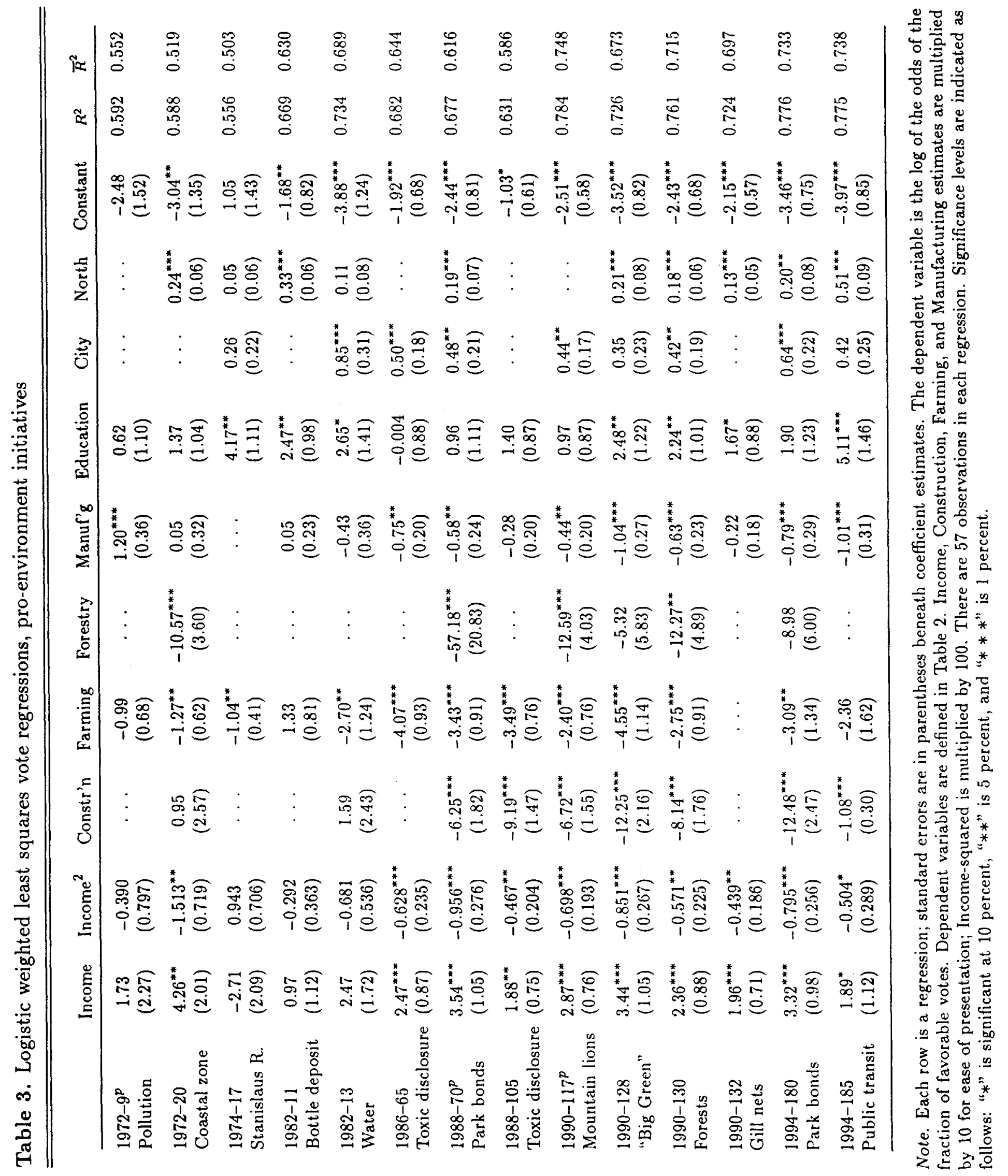


Table 4. Estimates of the income effect at mean and maximum income

\begin{tabular}{|c|c|c|c|c|c|c|c|c|c|}
\hline \multirow[b]{2}{*}{ Initiative } & \multirow[b]{2}{*}{$\begin{array}{c}\text { Income } \\
\text { Min-Max }\end{array}$} & \multicolumn{4}{|c|}{ Table 3 specification } & \multicolumn{4}{|c|}{ Income-only specification } \\
\hline & & $\begin{array}{l}\text { Derivative } \\
\text { at mean } \\
\text { (1) }\end{array}$ & $F$ & $\begin{array}{l}\text { Derivative } \\
\text { at } \max \\
(2)\end{array}$ & $F$ & $\begin{array}{l}\text { Derivative } \\
\text { at mean } \\
(3)\end{array}$ & I & $\begin{array}{l}\text { Derivative } \\
\text { at } \max \\
(4)\end{array}$ & $F$ \\
\hline $\begin{array}{l}1972-9^{p} \\
\text { Pollution }\end{array}$ & $9.2-17.3$ & 0.82 & $\begin{array}{l}3.03^{*} \\
{[4.35]^{* *}}\end{array}$ & 0.38 & $\begin{array}{l}0.45 \\
{[0.47]}\end{array}$ & 2.08 & $36.22^{* * *}$ & -0.65 & 1.39 \\
\hline $\begin{array}{l}1972-20 \\
\text { Coastal zone }\end{array}$ & $9.2-17.3$ & 0.74 & $\begin{array}{l}3.14^{*} \\
{[3.83]^{*}}\end{array}$ & -0.98 & $\begin{array}{l}3.20^{*} \\
{[3.12]^{*}}\end{array}$ & 1.13 & $12.59^{* * *}$ & -0.12 & 0.05 \\
\hline $\begin{array}{l}1974-17 \\
\text { Stanislaus R. }\end{array}$ & $9.6-24.6$ & -0.41 & $\begin{array}{l}0.84 \\
{[1.41]}\end{array}$ & 1.93 & $\begin{array}{l}1.82 \\
{[2.70]}\end{array}$ & 1.20 & $12.73^{* * *}$ & -0.79 & 0.28 \\
\hline $\begin{array}{l}1982-11 \\
\text { Bottle deposit }\end{array}$ & $8.8-21.8$ & 0.27 & $\begin{array}{l}0.76 \\
{[0.67]}\end{array}$ & -0.30 & $\begin{array}{l}0.31 \\
{[0.41]}\end{array}$ & 0.08 & 0.09 & 1.81 & $8.65^{* * *}$ \\
\hline $\begin{array}{l}\text { 1982-13 } \\
\text { Water }\end{array}$ & $8.8--21.8$ & 0.84 & $\begin{array}{l}2.47 \\
{[2.56]}\end{array}$ & -0.50 & $\begin{array}{l}0.45 \\
{[0.77]}\end{array}$ & 2.13 & $46.61^{* * *}$ & 0.10 & 0.02 \\
\hline $\begin{array}{l}1986-65 \\
\text { Toxic disclosure }\end{array}$ & $9.4--25.3$ & 0.79 & $\begin{array}{l}6.44^{* *} \\
{[3.43]^{*}}\end{array}$ & -0.70 & $\begin{array}{l}2.92^{*} \\
{[2.62]}\end{array}$ & 1.18 & $43.55^{* * *}$ & -0.91 & $4.22^{* *}$ \\
\hline $\begin{array}{l}1988-70^{p} \\
\text { Park bonds }\end{array}$ & $9.0-26.0$ & 0.93 & $\begin{array}{l}6.54^{* *} \\
{[3.55]^{*}}\end{array}$ & -1.44 & $\begin{array}{l}9.11^{* * *} \\
{[3.75]^{*}}\end{array}$ & 1.17 & $37.43^{* * *}$ & -1.11 & $5.08^{* *}$ \\
\hline $\begin{array}{l}1988-105 \\
\text { Toxic disclosure }\end{array}$ & $9.0-26.0$ & 0.61 & $\begin{array}{l}5.77^{* *} \\
{[4.48]^{* *}}\end{array}$ & -0.55 & $\begin{array}{l}2.01 \\
{[1.45]}\end{array}$ & 0.72 & $15.18^{* * *}$ & -0.64 & 1.93 \\
\hline $\begin{array}{l}1990-117^{p} \\
\text { Mountain lions }\end{array}$ & $9.5-26.5$ & 0.94 & $\begin{array}{l}11.54^{* * *} \\
{[9.37]^{* * *}}\end{array}$ & -0.83 & $\begin{array}{l}5.71^{* *} \\
{[4.32]^{* *}}\end{array}$ & 1.26 & $50.05^{* * *}$ & -1.02 & $5.61^{* *}$ \\
\hline $\begin{array}{l}\text { 1990-128 } \\
\text { "Big Green" }\end{array}$ & $9.5-26.5$ & 1.09 & $\begin{array}{l}8.22^{* * *} \\
{[6.30]^{* *}}\end{array}$ & -1.07 & $\begin{array}{l}5.25^{* *} \\
{[5.31]^{* *}}\end{array}$ & 1.22 & $25.47^{* * *}$ & -0.36 & 0.47 \\
\hline $\begin{array}{l}\text { 1990-130 } \\
\text { Forests }\end{array}$ & $9.5-26.5$ & 0.78 & $\begin{array}{l}6.05^{* *} \\
{[4.71]^{* *}}\end{array}$ & -0.67 & $\begin{array}{l}2.81 \\
{[2.56]}\end{array}$ & 1.15 & $37.36^{* * *}$ & -0.19 & 0.18 \\
\hline $\begin{array}{l}1990-132 \\
\text { Gill nets }\end{array}$ & $9.5-26.5$ & 0.75 & $\begin{array}{l}8.89^{* * *} \\
{[6.47]^{* *}}\end{array}$ & -0.36 & $\begin{array}{l}1.09 \\
{[1.12]}\end{array}$ & 0.94 & $47.39^{* * *}$ & 0.31 & 0.82 \\
\hline $\begin{array}{l}1994-180^{p} \\
\text { Park bonds }\end{array}$ & $8.3-25.7$ & 1.19 & $\begin{array}{l}10.30^{* * *} \\
{[12.00]^{* * *}}\end{array}$ & -0.77 & $\begin{array}{l}2.85^{*} \\
{[2.86]^{*}}\end{array}$ & 1.47 & $45.30^{* * *}$ & -0.45 & 0.78 \\
\hline $\begin{array}{l}1994-185 \\
\text { Public transit }\end{array}$ & $8.3-25.7$ & 0.54 & $\begin{array}{l}1.58 \\
{[1.61]}\end{array}$ & -0.70 & $\begin{array}{l}1.97 \\
{[2.07]}\end{array}$ & 1.47 & $20.59^{* * \pi}$ & 1.02 & $3.53^{*}$ \\
\hline
\end{tabular}

Note. Income Min-Max indicates the minimum and maximum county mean income. The derivative is of the $\log$-of-the-odds with respect to income, evaluated at the mean or maximum income (multiplied by 10 for ease of presentation). The income-only specification corresponds to regressions with only three explanatory variables, income, income-squared, and a constant. The $F$ statistic is for the hypothesis that the derivative to the left is equal to zero; the $F$ in square brackets is based on estimates from pooled regressions. Significance levels are indicated as follows: "*" is 10 percent, "**" is 5 percent, and "***" is 1 percent. 


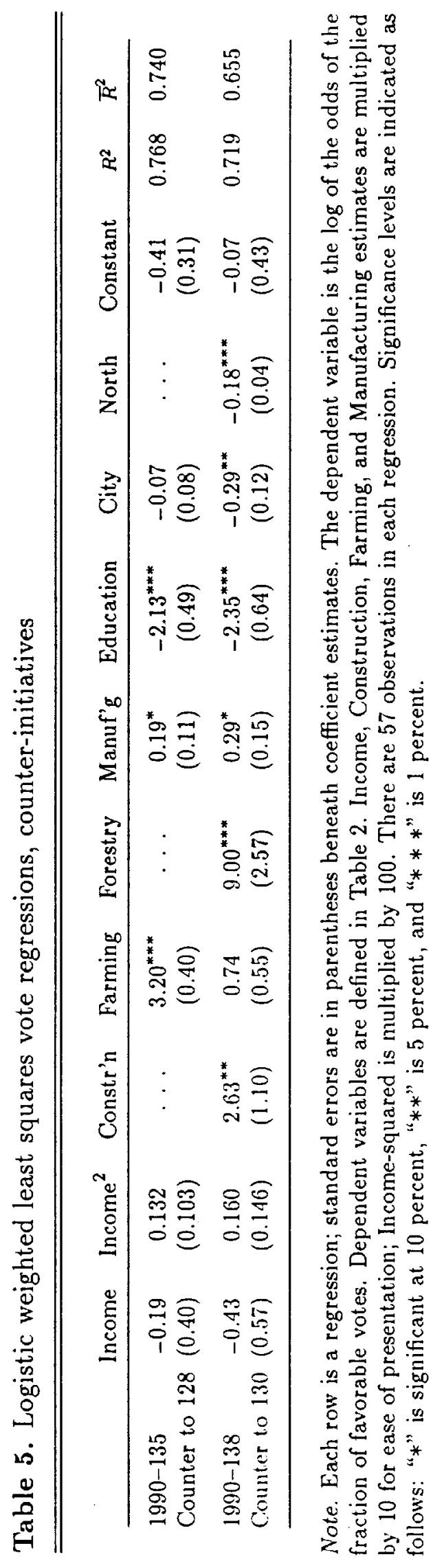


Table 6. $R^{2}$ 's from regressions with different explanatory variables

\begin{tabular}{|c|c|c|c|c|c|c|}
\hline Proposition & $\begin{array}{l}\text { Table } 3 \\
\text { (1) }\end{array}$ & $\begin{array}{l}\text { Income, } \\
\text { Income } \\
(2)\end{array}$ & $\begin{array}{c}\text { Constr'n } \\
\text { Farming, } \\
\text { Forestry, } \\
\text { Manuf'g } \\
\quad(3)\end{array}$ & $\begin{array}{l}\text { Education } \\
\text { (4) }\end{array}$ & $\begin{array}{c}\text { Table 3, } \\
\text { Democrats } \\
(5)\end{array}$ & $\begin{array}{c}(5)-(1) \\
(6)\end{array}$ \\
\hline $\begin{array}{l}1972-9^{p} \\
\text { Pollution }\end{array}$ & $\begin{array}{c}0.592 \\
{[0.552]}\end{array}$ & $\begin{array}{c}0.451 \\
{[0.431]}\end{array}$ & $\begin{array}{c}0.468 \\
{[0.488]}\end{array}$ & $\begin{array}{c}0.164 \\
{[0.149]}\end{array}$ & $\begin{array}{c}0.641 \\
{[0.598]}\end{array}$ & $\begin{array}{c}0.049 \\
{[0.046]}\end{array}$ \\
\hline $\begin{array}{l}1972-20 \\
\text { Coastal zone }\end{array}$ & $\begin{array}{c}0.588 \\
{[0.519]}\end{array}$ & $\begin{array}{c}0.242 \\
{[0.214]}\end{array}$ & $\begin{array}{c}0.312 \\
{[0.260]}\end{array}$ & $\begin{array}{c}0.321 \\
{[0.309]}\end{array}$ & $\begin{array}{c}0.738 \\
{[0.688]}\end{array}$ & $\begin{array}{c}0.150 \\
{[0.169]}\end{array}$ \\
\hline $\begin{array}{l}1974-17 \\
\text { Stanislaus R. }\end{array}$ & $\begin{array}{c}0.556 \\
{[0.503]}\end{array}$ & $\begin{array}{c}0.265 \\
{[0.238]}\end{array}$ & $\begin{array}{c}0.213 \\
{[0.198]}\end{array}$ & $\begin{array}{c}0.468 \\
{[0.458]}\end{array}$ & $\begin{array}{c}0.579 \\
{[0.519]}\end{array}$ & $\begin{array}{c}0.023 \\
{[0.016]}\end{array}$ \\
\hline $\begin{array}{l}\text { 1982-11 } \\
\text { Bottle deposit }\end{array}$ & $\begin{array}{c}0.669 \\
{[0.630]}\end{array}$ & $\begin{array}{c}0.245 \\
{[0.217]}\end{array}$ & $\begin{array}{c}0.012 \\
{[-0.025]}\end{array}$ & $\begin{array}{c}0.331 \\
{[0.319]}\end{array}$ & $\begin{array}{c}0.728 \\
{[0.689]}\end{array}$ & $\begin{array}{c}0.059 \\
{[0.059]}\end{array}$ \\
\hline $\begin{array}{l}\text { 1982-13 } \\
\text { Water }\end{array}$ & $\begin{array}{c}0.734 \\
{[0.689]}\end{array}$ & $\begin{array}{c}0.638 \\
{[0.625]}\end{array}$ & $\begin{array}{c}0.552 \\
{[0.527]}\end{array}$ & $\begin{array}{c}0.515 \\
{[0.507]}\end{array}$ & $\begin{array}{c}0.925 \\
{[0.911]}\end{array}$ & $\begin{array}{c}0.191 \\
{[0.222]}\end{array}$ \\
\hline $\begin{array}{l}1986-65 \\
\text { Toxic disclosure }\end{array}$ & $\begin{array}{c}0.682 \\
{[0.644]}\end{array}$ & $\begin{array}{c}0.482 \\
{[0.463]}\end{array}$ & $\begin{array}{c}0.414 \\
{[0.392]}\end{array}$ & $\begin{array}{c}0.278 \\
{[0.264]}\end{array}$ & $\begin{array}{c}0.774 \\
{[0.742]}\end{array}$ & $\begin{array}{c}0.092 \\
{[0.098]}\end{array}$ \\
\hline $\begin{array}{l}1988-70^{p} \\
\text { Park bonds }\end{array}$ & $\begin{array}{c}0.677 \\
{[0.616]}\end{array}$ & $\begin{array}{c}0.440 \\
{[0.419]}\end{array}$ & $\begin{array}{c}0.396 \\
{[0.350]}\end{array}$ & $\begin{array}{c}0.294 \\
{[0.281]}\end{array}$ & $\begin{array}{c}0.858 \\
{[0.827]}\end{array}$ & $\begin{array}{c}0.181 \\
{[0.211]}\end{array}$ \\
\hline $\begin{array}{l}1988-105 \\
\text { Toxic disclosure }\end{array}$ & $\begin{array}{c}0.631 \\
{[0.586]}\end{array}$ & $\begin{array}{c}0.244 \\
{[0.216]}\end{array}$ & $\begin{array}{c}0.438 \\
{[0.407]}\end{array}$ & $\begin{array}{c}0.144 \\
{[0.128]}\end{array}$ & $\begin{array}{c}0.801 \\
{[0.773]}\end{array}$ & $\begin{array}{c}0.170 \\
{[0.187]}\end{array}$ \\
\hline $\begin{array}{l}1990-117^{p} \\
\text { Mountain lions }\end{array}$ & $\begin{array}{c}0.784 \\
{[0.748]}\end{array}$ & $\begin{array}{c}0.515 \\
{[0.497]}\end{array}$ & $\begin{array}{c}0.453 \\
{[0.411]}\end{array}$ & $\begin{array}{c}0.331 \\
{[0.319]}\end{array}$ & $\begin{array}{c}0.802 \\
{[0.764]}\end{array}$ & $\begin{array}{c}0.018 \\
{[0.016]}\end{array}$ \\
\hline $\begin{array}{l}\text { 1990-128 } \\
\text { "Big Green" }\end{array}$ & $\begin{array}{c}0.726 \\
{[0.673]}\end{array}$ & $\begin{array}{c}0.410 \\
{[0.388]}\end{array}$ & $\begin{array}{c}0.263 \\
{[0.206]}\end{array}$ & $\begin{array}{c}0.368 \\
{[0.356]}\end{array}$ & $\begin{array}{c}0.936 \\
{[0.922]}\end{array}$ & $\begin{array}{c}0.210 \\
{[0.249]}\end{array}$ \\
\hline $\begin{array}{l}1990-130 \\
\text { Forests }\end{array}$ & $\begin{array}{c}0.761 \\
{[0.715]}\end{array}$ & $\begin{array}{c}0.517 \\
{[0.499]}\end{array}$ & $\begin{array}{c}0.321 \\
{[0.268]}\end{array}$ & $\begin{array}{c}0.488 \\
{[0.479]}\end{array}$ & $\begin{array}{c}0.925 \\
{[0.908]}\end{array}$ & $\begin{array}{c}0.164 \\
{[0.193]}\end{array}$ \\
\hline $\begin{array}{l}1990-132 \\
\text { Gill nets }\end{array}$ & $\begin{array}{c}0.724 \\
{[0.697]}\end{array}$ & $\begin{array}{c}0.628 \\
{[0.614]}\end{array}$ & $\begin{array}{c}0.104 \\
{[0.088]}\end{array}$ & $\begin{array}{c}0.656 \\
{[0.650]}\end{array}$ & $\begin{array}{c}0.791 \\
{[0.766]}\end{array}$ & $\begin{array}{c}0.067 \\
{[0.069]}\end{array}$ \\
\hline $\begin{array}{l}1994-180^{p} \\
\text { Park bonds }\end{array}$ & $\begin{array}{c}0.776 \\
{[0.733]}\end{array}$ & $\begin{array}{c}0.539 \\
{[0.522]}\end{array}$ & $\begin{array}{c}0.311 \\
{[0.258]}\end{array}$ & $\begin{array}{c}0.433 \\
{[0.423]}\end{array}$ & $\begin{array}{c}0.911 \\
{[0.892]}\end{array}$ & $\begin{array}{c}0.135 \\
{[0.159]}\end{array}$ \\
\hline $\begin{array}{l}\text { 1994-185 } \\
\text { Public transit }\end{array}$ & $\begin{array}{c}0.775 \\
{[0.738]}\end{array}$ & $\begin{array}{c}0.550 \\
{[0.534]}\end{array}$ & $\begin{array}{c}0.173 \\
{[0.126]}\end{array}$ & $\begin{array}{c}0.602 \\
{[0.595]}\end{array}$ & $\begin{array}{c}0.919 \\
{[0.903]}\end{array}$ & $\begin{array}{c}0.144 \\
{[0.165]}\end{array}$ \\
\hline $\begin{array}{l}1990-135 \\
\text { Counter to } 128\end{array}$ & $\begin{array}{c}0.768 \\
{[0.740]}\end{array}$ & $\begin{array}{c}0.369 \\
{[0.346]}\end{array}$ & $\begin{array}{c}0.621 \\
{[0.592]}\end{array}$ & $\begin{array}{c}0.398 \\
{[0.387]}\end{array}$ & $\begin{array}{c}0.821 \\
{[0.796]}\end{array}$ & $\begin{array}{c}0.053 \\
{[0.056]}\end{array}$ \\
\hline $\begin{array}{l}1990-138 \\
\text { Counter to } 130\end{array}$ & $\begin{array}{c}0.719 \\
{[0.655]}\end{array}$ & $\begin{array}{c}0.382 \\
{[0.359\}}\end{array}$ & $\begin{array}{c}0.242 \\
{[0.184]}\end{array}$ & $\begin{array}{c}0.499 \\
{[0.490]}\end{array}$ & $\begin{array}{c}0.840 \\
{[0.805]}\end{array}$ & $\begin{array}{c}0.121 \\
{[0.150]}\end{array}$ \\
\hline Combined & 0.715 & 0.473 & 0.325 & 0.419 & 0.843 & 0.128 \\
\hline
\end{tabular}

Note. Columns (1) to (5) report the $R^{2}$ 's from weighted OLS voting regressions where the independent variables are indicated at the top of the column. Each regression has 57 observations. "Combined" is the total explained variation over all 16 initiatives. 


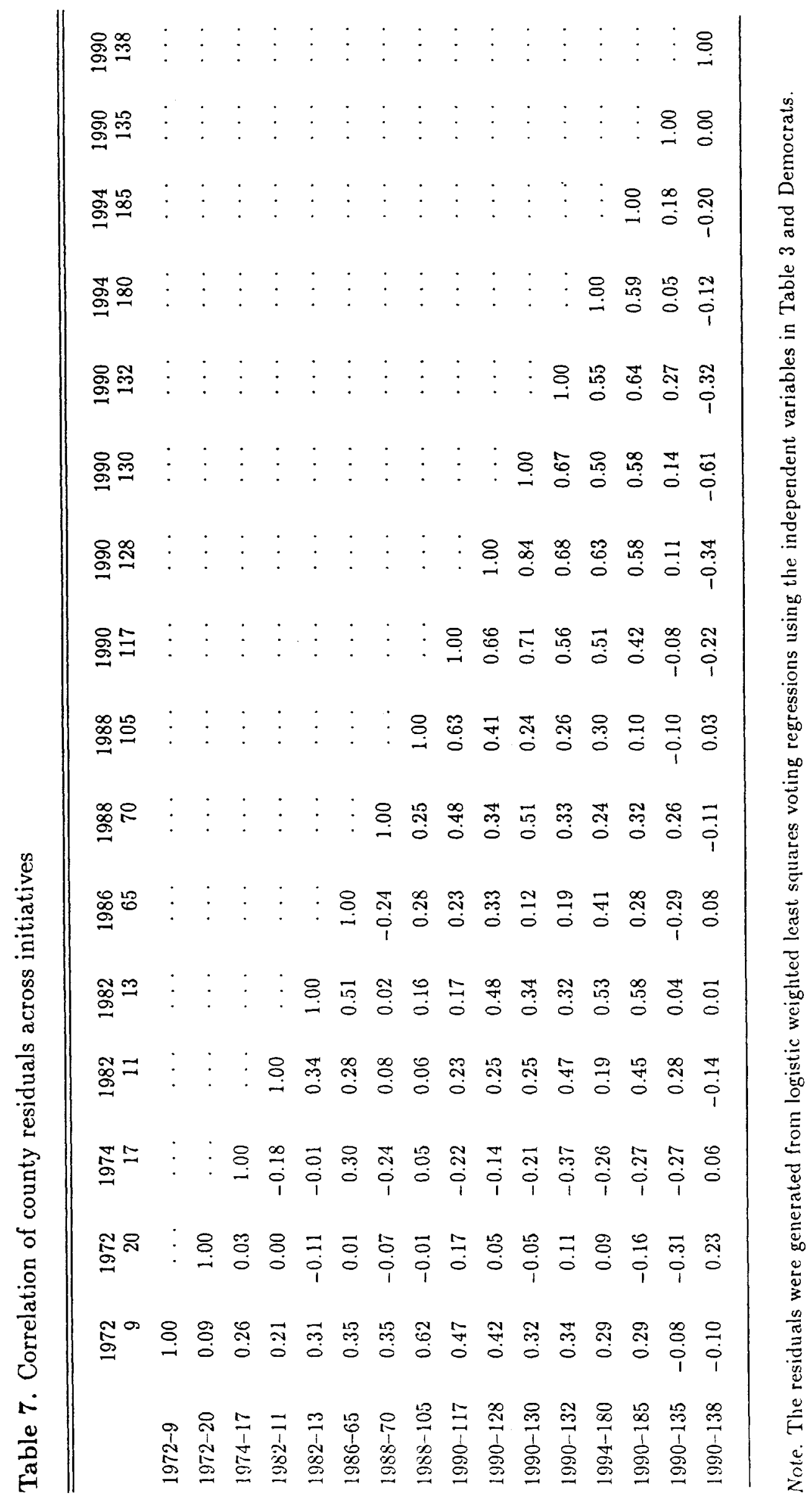




\section{4-1995 Discussion Paper Series \\ Department of Economics \\ Columbia University \\ 1022 International Affairs Bldg. \\ 420 West 118th Street \\ New York, N.Y., 10027}

The following papers are published in the 1994-95 Columbia University Discussion Paper series which runs from early November to October 31 (Academic Year). Domestic orders for discussion papers are available for purchase at $\$ 8.00$ (US) each and $\$ 140.00$ (US) for the series. Foreign orders cost $\$ 10.00$ (US) for individual paper and $\$ 185.00$ for the series. To order discussion papers, please send your check or money order payable to Department of Economics, Columbia University to the above address. Be sure to include the series number for the paper when you place an order.

708. Trade and Wages: Choosing among Alternative Explanations Jagdish Bhagwati

709. Dynamics of Canadian Welfare Participation

Garrey F. Barret, Michael I. Cragg

710. Much Ado About Nothing? Capital Market Reaction to Changes in Antitrust Precedent concerning Exclusive Territories.

Sherry A. Glied, Randall S. Kroszner

711. The Cost of Diabetes

Matthew Kahn

712. Evidence on Unobserved Polluter Abatement Effort

Matthew E. Kahn

713. The Premium for Skills: Evidence from Mexico

Michael Cragg

714. Measuring the Incentive to be Homeless

Michael Cragg, Mario Epelaum

715. The WTO: What Next?

Jagdish Bhagwati

716. Do Converters Facilitate the Transition to a New Incompatible Technology?

A Dynamic Analysis of Converters

Jay Phil Choi

716A. Shock Therapy and After: Prospects for Russian Reform

Padma Desai

717. Wealth Effects, Distribution and The Theory of Organization

-Andrew F. Newman and Patrick Legros 
718. Trade and the Environment: Does Environmental Diversity Detract from the Case for Free Trade?

-Jagdish Bhagwati and T.N. Srinivasan (Yale Univ)

719. US Trade Policy: Successes and Failures

-Jagdish Bhagwati

720. Distribution of the Disinflation of Prices in 1990-91 Compared with Previous Business Cycles

-Philip Cagan

721. Consequences of Discretion in the Formation of Commodities Policy

-John McLaren

722. The Provision of (Two-Way) Converters in the Transition Process to a New Incompatible Technology

-Jay Pil Choi

723. Globalization, Sovereignty and Democracy

-Jagdish Bhagwati

724. Preemptive R\&D, Rent Dissipation and the "Leverage Theory"

-Jay Pil Choi

725. The WTO's Agenda: Environment and Labour Standards, Competition Policy and the Question of Regionalism

-Jagdish Bhagwati

726. US Trade Policy: The Infatuation with FTAs

-Jagdish Bhagwati

727. Democracy and Development: New Thinking on an Old Question -Jagdish Bhagwati

728. The AIDS Epidemic and Economic Policy Analysis -David E. Bloom, Ajay S. Mahal

729. Economics of the Generation and Management of Municipal Solid Waste -David E. Bloom, David N. Beede

730. Does the AIDS Epidemic Really Threaten Economic Growth?

-David E. Bloom, Ajay S. Mahal

731. Big-City Governments

-Brendan O'Flaherty

732. International Public Opinion on the Environment

-David Bloom 
733. Is an Integrated Regional Labor Market Emerging in the East and Southeast Asia? -David Bloom, Waseem Noor

734. Migration, Integration and Development -Abhijit V. Banerjee, Andrew Newman

735. Infrastructure, Human Capital and International Trade -Ronald Findlay

736. Short Ballots: Why Mayors Are in Charge of So Many Different Things -Brendan O'Flaherty

737. Demand for Environmental Goods: Evidence from Voting Patterns on California Initiatives -Matthew Kahn and John Matsusaka 